\title{
PRODUKSI DAN KANDUNGAN FLAVONOID UMBI TANAMAN BAWANG DAYAK (Eleutherine palmifolia) DENGAN PEMBERIAN NPK 16:16:16 PADA BERBAGAI UMUR PANEN
}

\section{Production and Flavonoid Content of Dayak Onion (Eleutherine palmifolia) with Application of NPK 16:16:16 at Various Ages of Harvesting}

\author{
T. Rosmawaty, Hasan Basri Jumin, Mardaleni, Charles Sinaga \\ Program Studi Agroteknologi, Fakultas Pertanian, Universitas Islam Riau, Pekanbaru \\ Jalan Kaharuddin Nasution Km. 113 Pekanbaru 28284 Riau \\ email: T.Rosmawaty@agr.uir.ac.id.
}

\begin{abstract}
The objectives of this research are to find out the number of dayak onion production at various ages of harvest by providing NPK fertilizer 16.16.16. and to find out the content of Flavonoids at various ages with NPK 16:16:16 fertilizer application. The research was conducted at the Experimental Garden of Islamic University of Riau during 6 months, starting from March to August 2018. The completely randomized design with factorial $3 \times 4$ was used. Data were analyzed descriptive approach. The parameters observed were the number of clump tubers, clump tubers dry weight, simplicia dry weight, flavonoid content, phenolic content and antioxidant activity. The results showed that the interaction of NPK 16:16: 16 dosages and harvesting age had no effect on the all observed parameters. The best treatment of NPK 16:16:16 2,5 g/plant (N3) for optimum production and $1,25 \mathrm{~g} /$ plant $(\mathrm{N} 1)$ for maximum total flavonoid content. With the best treatment of NPK 16:16:16 2.5 g/plant $(\mathrm{N} 3)$ for maximum production and $1.25 \mathrm{~g} / \mathrm{plant}(\mathrm{N} 1)$ for maximum total flavonoid content. For optimal age and 5 (months) for maximum total flavonoid content.
\end{abstract}

Keywords: Dayak Onion, Harvest age, Flavonoids

\begin{abstract}
ABSTRAK
Tujuan penelitian 1). Untuk memgetahui besarnya produksi bawang dayak pada berbagai umur panen dengan pemberian pupuk NPK16.16.16. 2). Untuk mengetahui kandungan Flavonoid pada berbagai umur panen dengan pemberian pupuk NPK 16:16:16. Penelitian ini merupakan penelitian lanjutan yang dilaksanakan di Kebun Percobaan Fakultas Pertanian Universitas Islam Riau, penelitian ini akan dilaksanakan selama 6 bulan yang akan dimulai dari bulan Maret-Agustus 2018. Rancangan percobaan yang digunakan adalah RAL Faktorial 3x4. Data analisis kandungan Flavonoid umbi bawang dayak disajikan secara deskriptif. Parameter yang diamati adalah jumlah umbi per rumpun, berat kering per rumpun, berat kering simplisia, kandungan flavonoid, kandungan fenolik dan aktifitas antioksidan. Hasil penelitian menunjukkan interaksi dosis pupuk NPK 16:16:16 dan umur panen yang berbeda tidak berpengaruh nyata terhadap semua parameter yang diamati. Pengaruh dosis pupuk NPK 16:16:16 dan umur panen yang berbeda memberikan pengaruh nyata terhadap semua parameter yang dimati. Dengan perlakuan terbaik NPK 16:16:16 2,5 g/tanaman (N3) untuk produksi yang maksimal dan 1,25 g/tanaman (N1) untuk kandungan total flavonoid yang maximal. Sedangkan umur panen yang terbaik ialah pada umur 6 bulan (U2) untuk produksi yang maksimal dan 5 (bulan) untuk kandungan total flavonoid yang maksimal
\end{abstract}

Kata Kunci: Bawang dayak, Umur panen, Flavonoid

\section{PENDAHULUAN}

Umbi bawang dayak merupakan salah satu sumber flavonoid yang berpotensi sebagai antioksidan. Kemampuan flavonoid sebagai anti oksidan telah banyak diteliti belakangan ini (Sulastri,dkk., 2015; Pratiwi, dkk., 2013; Febrinda, dkk., 2013; Kuntorini, dkk., 2010) Kandungan flavonoid dalam umbi bawang 
dayak inilah yang mendorong dilakukannya suatu usaha yang dapat mengoptimalkan pemanfaatan tanaman tersebut.

Namun permasalahan bawang dayak saat ini belum begitu populer dimasyarakat Indonesia, mayoritas belum mengetahui fungsi dan manfaat bawang dayak sebagai obat bermacam penyakit, padahal bawang dayak memiliki prospek yang baik sebagai bahan baku obat. Potensi bawang dayak sebagai tanaman obat multi fungsi sangat besar sehingga perlu ditingkatkan penggunaannya sebagai bahan baku obat modern. Pengobatan secara tradisional tidak memiliki efek samping sama sekali dan harganya pun terjangkau bagi masyarakat. Untuk itu perlu dilakukan beberapa upaya untuk meningkatkan minat masyarakat terhadap tanaman bawang dayak. Beberapa uapaya yang dapat dilakukan untuk meningkat minat masyarakat dan produksi bawang dayak di Indonesia adalah. 1). Memberikan informasi dan penyuluhan kepada para petani. 2). Penerapan teknik budidaya yang tepat baik cara pemupukan, perawatan, pengendalaian hama dan penyakit dan waktu panen yang tepat. 3). Melakukan penelitian-penelitian mengenai budidaya untuk meningkatkan produksi dan kandungan bahan aktif pada tanaman bawang dayak. Salah satu penelitian yang dapat dilakukan ialah penelitian tentang pemupukan dan umur panen.

Salah satu faktor penentu keberhasilan tanaman yang kita budidayakan agar dapat tumbuh dan berproduksi dengan baik adalah ketersediaan unsur hara yang tersedia dalam media tanam. Untuk itu penyediaan unsur hara bagi tanaman dapat dilakukan dengan cara pemupukan. Melalui pemupukan tanaman tersebut akan dapat dapat tumbuh optimal dan berproduksi maksimal. Salah satu sumber pupuk yang mengandung unsur N, P dan K adalah NPK Mutara 16:16:16. Penggunaan Pupuk NPK 16:16:16 mutiara dapat digunakan untuk semua jenis tanaman serta berbagai kondisi lahan, iklim dan lingkungan. Pupuk ini sangat cocok untuk pemupukan dasar atau susulan dan dapat juga memberikan keseimbangan hara yang baik bagi pertumbuhan tanaman, sehingga dapat mendukung tanaman untuk tumbuh dan berkembang dengan baik.

Selain pemupukan, umur panen juga mempengaruhi produksi dan kandungan bahan aktif pada bawang dayak. Bawang dayak Pada umumnya bawang dayak sudah dapat di panen pada umur 4-5 bulan setelah penanaman, yang ditandai dengan tanaman telah mengeluarkan bunga berwarna putih. namun kondisi geografis dan umur panen yang berbeda pada tanaman bawang dayak dapat mempengaruhi produksi dan kandungan senyawa aktif seperti favonoid yang terdapat didalam umbi bawang Dayak. Permasalahan Saat ini, petani belum mengetahui apakah ada perbedaan kandungan bahan aktif pada bawang dayak yang berumur 5, 6 dan 7 bulan, sehingga penelitian tentang umur panen perlu dilakukan.

\section{METODE PENELITIAN}

Penelitian ini dilaksanakan di Kebun Percobaan Fakultas Pertanian Universitas Islam Riau, Jalan Kaharuddin Nasution Km 11, Kelurahan Air Dingin, Kecamatan Bukit Raya, Marpoyan, Kota Pekanbaru, Sedangkan untuk analaisa senyawa aktif umbi bawang dayak dilakukan di Laboratorium Kimia Organik Universitas Riau, Pekanbaru. Penelitian ini dilaksanakan selama 6 bulan yang dimulai dari bulan Maret sampai Agustus 2018.

Bahan yang digunakan dalam penelitian ini adalah umbi bawang dayak, polybag ukuran 35 x $40 \mathrm{~cm}$, pupuk NPK Mutiara 16:16:16, furadan, decis, dithane M-45, seng plat, paku, cat, kuas. Alat yang digunakan adalah cangkul, parang, gergaji, palu, handsprayer, gembor, meteran, timbangan analitik, tali, gunting, alat tulis dan kamera. Dan alat laboratorium yang menunjang analisa kimia umbi bawang dayak.

Rancangan percobaan yang digunakan adalah RAL Faktorial 4x3. Faktor pertama adalah permberian NPK 16:16:16 yang terdiri dari 4 taraf. Faktor kedua adalah berbagai umur panen yang terdiri dari 3 taraf. Hasil dianalisis secara statistik dan diuji lanjut dengan BNJ pada taraf 5\%. Data analisis kandungan Favomnoid umbi bawang dayak disajikan secara deskriptif. Adapun kombinasi perlakuan NPK $(\mathrm{N})$ dan berbagai umur panen (U) terdiri dari $: \mathrm{N} 0=$ tanpa pupuk NPK, N1= 1,25 $\mathrm{g} /$ polibag $(200 \mathrm{~kg} / \mathrm{ha}), \mathrm{N} 2=1,87 \mathrm{~g} /$ polybag 
(300 kg/ha), N3 =2,50 g /polybag (400 kg/ha). Sedangkan Umur panen ( $\mathrm{U}$ ) U1 = umur 5 bulan, $\mathrm{U} 2=$ umur 6 bulan ,U3 = umur 7 bulan. Terdapat 12 kombinasi perlakuan dengan 3 ulangan.

Pelaksanaan Penelitian yang dilakukan adalah Persiapan Lahan, Penyusunan Polybag, Pemasangan Label, Persiapan bahan tanaman/umbi, Penanaman, Pemberian perlakuan (NPK Mutiara 16:16:16, Umur panen), Pemeliharaan (Penyiraman, Penyiangan, Pengendalian hama dan penyakit). Parameter yang diamati adalah jumlah umbi perumpun, berat kering perrumpun, Berat Kering Simplisia, Kandungan Flavonoid, kandungan fenolik dan aktifitas antioksidan.

Tabel 1. Rerata jumlah umbi per rumpun tanaman dan umur panen yang berbeda.

\begin{tabular}{ccccc}
\hline \multirow{2}{*}{ NPK 16:16:16 (g/tanaman) } & \multicolumn{3}{c}{ Umur Panen (Bulan) } & \multirow{2}{*}{ Rerata } \\
\cline { 2 - 4 } N0 (0) & $\mathrm{U} 1(5)$ & $\mathrm{U} 2(6)$ & $\mathrm{U} 3(7)$ & $18,01 \mathrm{c}$ \\
N1 $(1,25)$ & 14,83 & 19,15 & 20,05 & $19,28 \mathrm{~b}$ \\
N2 $(1,87)$ & 16,67 & 20,27 & 20,89 & $19,91 \mathrm{ab}$ \\
N3 $(2,50)$ & 17,17 & 21,22 & 21,34 & $20,47 \mathrm{a}$ \\
\hline Rerata & 18,50 & 21,36 & 21,55 & \\
\hline \multicolumn{7}{c}{$16,79 \mathrm{~b}$} & $20,50 \mathrm{a}$ & $20,96 \mathrm{a}$ & \\
\hline
\end{tabular}

Angka-angka pada baris dan kolom yang diikuti huruf kecil yang sama menunjukan tidak berbeda nyata menurut uji lanjut BNJ pada taraf $5 \%$.

Pada tabel 1 terlihat jumlah umbi tanaman bawang dayak meningkat dari umur panen 5 bulan (U1) ke umur panen 6 bulan (U2) jumlah umbi tanaman bawang dayak meningkat dengan bertambahnya umur panen diduga disebabkan oleh semakin lama kesempatan tanaman bawang dayak untuk hidup dan tumbuh. Sehingga hasil fotosintesis yang terakumulasi pada jaringan bertambah, hasil fotosintesis inilah yang nantinya digunakan oleh tanaman untuk proses pertumbuhannya, seperti penambahan jumlah umbi. namun pada umur panen 7 bulan (U3) jumlah umbi tanaman bawang dayak relatif sama dengan jumlah umbi tanaman bawang dayak pada umur 6 bulan. Hal ini diduga disebabkan oleh pertumbuhan tanaman bawang dayak sudah maximal, sehingga hasil fotosisntesis tak lagi digunakan untuk pertumbuhan vegetatif seperti aktifitas pembesaran, pemanjangan serta pembelahan sel melainkan digunakan oleh tanaman untuk

\section{HASIL DAN PEMBAHASAN}

\section{A. Jumlah Umbi Per Rumpun}

Hasil pengamatan terhadap jumlah umbi per rumpun tanaman bawang dayak dengan pemberian NPK 16:16:16 dan umur panen yang berbeda setelah dilakukan analisis sidik ragam memperlihatkan bahwa pemberian NPK 16:16:16 dan umur panen yang berbeda secara interaksi tidak berpengaruh nyata terhadap jumlah umbi per rumpun tanaman bawang dayak, namun pengaruh utama NPK 16:16:16 dan umur panen yang berbeda memberikan pengaruh yang nyata terhadap jumlah umbi per rumpun tanaman bawang dayak. Rata-rata jumlah umbi per rumpun tanaman bawang dayak dapat dilihat pada tabel 1 .

bawang dayak dengan pemberian NPK 16:16:16 
Tabel 2. Rerata berat kering tanaman bawang dayak dengan pemberian NPK 16:16:16 dan umur panen yang berbeda $(\mathrm{g})$.

\begin{tabular}{ccccc}
\hline \multirow{2}{*}{ NPK 16:16:16 (g/tanaman) } & \multicolumn{3}{c}{ Umur Panen (Bulan) } & \multirow{2}{*}{ Rerata } \\
\cline { 2 - 4 } & $\mathrm{U1}(5)$ & $\mathrm{U} 2(6)$ & $\mathrm{U} 3(7)$ & $20,14 \mathrm{c}$ \\
N0 $(0)$ & 19,11 & 19,91 & 21,41 & $21,00 \mathrm{c}$ \\
N1 $(1,25)$ & 20,20 & 21,10 & 21,71 & $22,53 \mathrm{~b}$ \\
N2 $(1,87)$ & 22,01 & 22,75 & 22,85 & $23,66 \mathrm{a}$ \\
N3 $(2,50)$ & 22,68 & 24,06 & 24,26 & $22,56 \mathrm{a}$ \\
\hline Rerata & $\mathrm{KK}=3,81 \%$ & BNJ N $=1,08$ & $21,95 \mathrm{a}$ & $\mathrm{BNJ} \mathrm{U}=0,84$ \\
\hline
\end{tabular}

Angka-angka pada baris dan kolom yang diikuti huruf kecil yang sama menunjukan tidak berbeda nyata menurut uji lanjut BNJ pada taraf $5 \%$.

Pemberian NPK 16:16:16 2,5 g/tanaman dapat meningkatkan berat kering tanaman diduga karena terpenuhinya kebutuhan unsur hara untuk pertumbuhan tanaman bawang dayak. Terutama unsur N, P dan K, Hal ini senada dengan pendapat Lakitan (2008) menyatakan bahwa tinggi rendahnya bahan kering tanaman tergantung dari banyak atau sedikitya serapan unsur hara oleh akar yang berlangsung selama proses pertumbuhan. Seperti unsur nitrogen, nitrogen merupakan salah satu unsur pembentuk klorofil. Klorofil mengandung pigmen yang dibutuhkan sebagai absorben cahaya matahari yang digunakan dalam proses fotosintesis. Apabila $\mathrm{N}$ meningkat maka klorofil juga meningkat sehingga fotosintat yang dihasilkan juga meningkat, sesuai dengan pendapat Sugeng (2015) yang mengatakan bahwa jika fotosintesis berlangsung dengan baik maka tanaman akan tumbuh dengan dan akar akan berkembang dengan baik pula serta diikuti dengan peningkatan berat kering tanaman.

\section{Berat Kering Simplisia}

Hasil pengamatan berat kering simplisia tanaman bawang dayak dengan pemberian NPK 16:16:16 dan umur panen yang berbeda setelah dilakukan analisis ragam memperlihatkan bahwa pemberian NPK 16:16:16 dan umur panen yang berbeda secara interaksi tidak berpengaruh nyata terhadap berat kering simplisia tanaman bawang dayak, namun pengaruh utama NPK 16:16:16 dan umur panen yang berbeda memberikan pengaruh yang nyata terhadap berat kering simplisia tanaman bawang dayak. Rata-rata berat kering simplisia tanaman bawang dayak dapat dilihat pada table 3.

Tabel 3. Rerata berat kering simplisia bawang dayak dengan pemberian NPK 16:16:16 dan umur panen yang berbeda $(\mathrm{g})$.

\begin{tabular}{ccccc}
\hline \multirow{2}{*}{ NPK 16:16:16 (g/tanaman) } & \multicolumn{3}{c}{ Umur Panen (Bulan) } & \multirow{2}{*}{ Rerata } \\
\cline { 2 - 4 } & U1 (5) & U2 (6) & U3 (7) & \\
\hline N0 $(0)$ & 25,18 & 25,44 & 28,20 & $26,28 \mathrm{~b}$ \\
N1 $(1,25)$ & 26,21 & 27,58 & 28,39 & $27,39 \mathrm{ab}$ \\
N2 $(1,87)$ & 27,80 & 28,67 & 29,00 & $28,49 \mathrm{a}$ \\
N3 $(2,50)$ & 28,08 & 28,65 & 28,57 & $28,43 \mathrm{a}$ \\
\hline Rerata & $26,82 \mathrm{~b}$ & $27,59 \mathrm{ab}$ & $28,54 \mathrm{a}$ & \\
\hline & $\mathrm{KK}=3,67 \%$ & BNJ N $=1,32$ & \multicolumn{2}{c}{ BNJ U $=1,03$} \\
\hline
\end{tabular}

Angka-angka pada baris dan kolom yang diikuti huruf kecil yang sama menunjukan tidak berbeda nyata menurut uji lanjut BNJ pada taraf $5 \%$.

Berat kering simplisia diduga erat hubungannya kandungan unsur hara, karena berat kering mencerminkan indikasi keberhasilan pertumbuhan tanaman. Berat kering merupakan petunjuk adanya hasil fotosintesis bersih yang dapat diendapkan setelah kadar airnya dikeringkan. Hal ini erat kaitannya dengan fotosintat yang dihasilkan dari proses fotosintesis yang digunakan untuk membangun jaringan dan sistem organ pada tanaman. Dengan meningkatnya tinggi tanaman, jumlah umbi, luas daun, serta berat 
segar tanaman, tentunya juga berkorelasi positif terhadap berat kering tanaman bawang dayak. Sesuai dengan pendapat Saragih, dkk (2013) yang mengatakan bahwa pupuk berperan dalam proses fotosintesis dimana pupuk sebagai salah satu penyuplai unsur hara yang dibutuhkan tanaman dalam proses metabolisme tanaman. Murbandono (2005), menyatakan bahan organik dapat berperan langsung sebagai sumber hara tanaman setelah mengalami proses

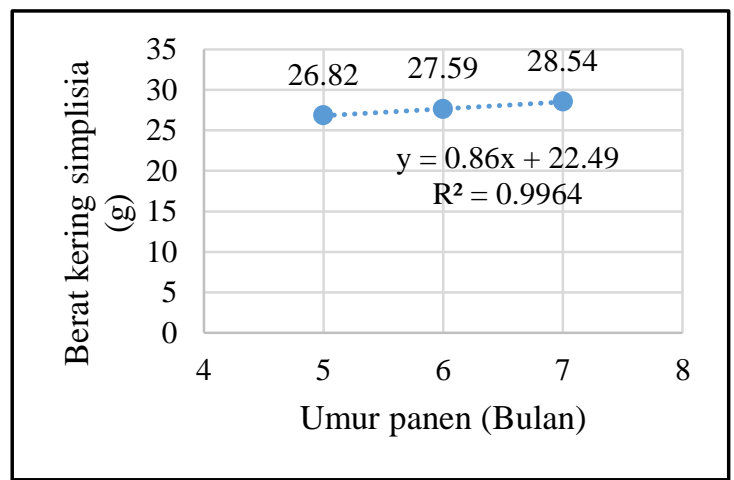

Gambar 3. Kurva hubungan umur panen NPK dengan Berat kering simplisia

Dari data pada gambar 3 terlihat pada hubungan umur panen dengan berat kering simplisia, didapatkan nilai $b=0,86$, sehingga dapat dikatakan untuk setiap x (umur panen) bertambah 1 bulan, maka y (berat kering simplisia) bertambah/ meningkat sebesar 0,86. Kurva regresi juga menunjukkan bahwa terdapat hubungan yang erat antara umur panen dengan berat kering simplisia. Hal ini diperlihatkan dengan nilai $r$ (koefisien korelasi), dan R2 (koefisien determinasi) diatas 0,90. Nilai $r$ menyatakan bahwa terdapat korelasi antara umur panen dengan berat kering simplisia. Dari nilai R2 ( $\mathrm{R}$ square) dapat diketahui bahwa terdapat keeratan hubungan yang signifikan antara umur panen dengan berat kering simplisia yang diamati dengan derajat keeratan sebesar 0,9999. Hal ini menunjukkan bahwa lebih dari $99 \%$ berat kering simplisia dipengaruhi oleh umur panen, sedangkan kurang dari $1 \%$ dipengaruhi oleh faktor lain.

Dari data pada gambar 4 terlihat pada hubungan dosis pupuk NPK 16:16:16 dengan kandungan total berat kering simplisia, didapatkan nilai $\mathrm{b}=1,77$, sehingga dapat dikatakan untuk setiap x (dosis NPK 16:16:16) mineralisasi dan secara tidak langsung dapat menciptakan suatu kondisi lingkungan pertumbuhan tanaman yang lebih baik dengan meningkatkan ketersediaan hara untuk mendukung pertumbuhan tanaman.

Kurva hubungan umur panen dan NPK dengan berat kering simplisia pada tanaman bawang dayak dapat dilihat pada Gambar 4 dan 5.

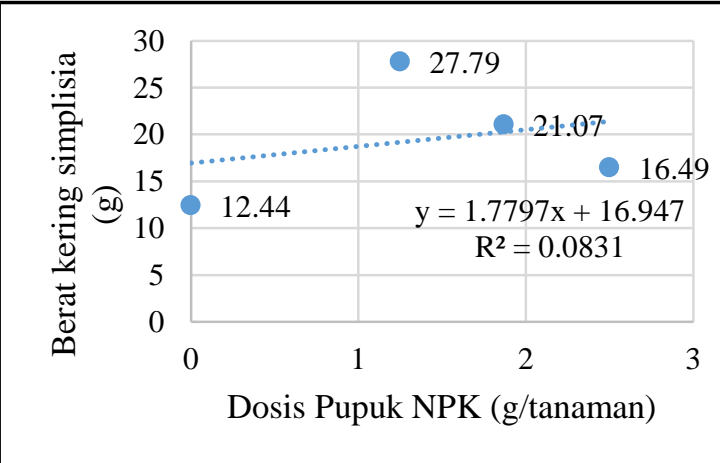

Gambar 4. Kurva hubungan pupuk dengan Berat kering simplisia

bertambah 1 taraf, maka y (berat kering simplisia) bertambah/ meningkat sebesar 1,77. Kurva regresi juga menunjukkan bahwa terdapat hubungan antara dosis NPK 16:16:16 dengan berat kering simplisia. Hal ini diperlihatkan dengan nilai $r$ (koefisien korelasi), dan R2 (koefisien determinasi) diatas 0,08. Nilai $r$ menyatakan bahwa terdapat korelasi antara dosis NPK 16:16:16 dengan berat kering simplisia. Dari nilai R2 ( $\mathrm{R}$ square) dapat diketahui bahwa terdapat keeratan hubungan yang signifikan antara dosis NPK 16:16:16 dengan berat kering simplisia yang diamati dengan derajat keeratan sebesar 0,08 . Hal ini menunjukkan bahwa lebih dari $8 \%$ berat kering simplisia dipengaruhi oleh dosis NPK 16:16:16, sedangkan kurang dari 92\% dipengaruhi oleh faktor lain.

\section{Kandungan total Flavonoid (mg kuarsetin/g berat kering)}

Berdasarkan hasil analisa laboratorium mengenai kandungan flavonoid pada tanaman bawang dayak dari dosis pemberian NPK 16:16:16 yang berbeda dan beberapa usia panen terdapat perbedaan antara satu dan yang 
lainnya. Untuk lebih jelasnya hubungan dosis pupuk dan kandungan total flavonoid dapat dilihat pada gambar 3 .

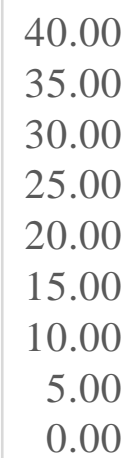

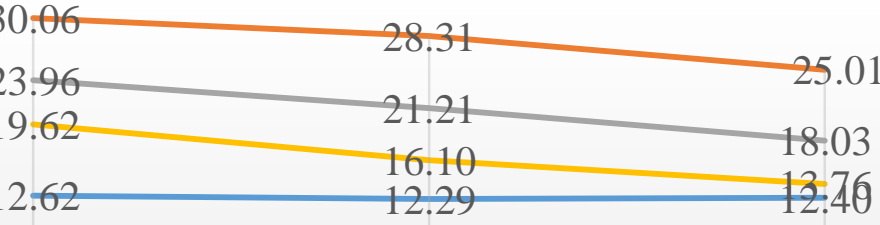

5 Bulan

6 Bulan

$\longrightarrow \mathrm{N} 0-\mathrm{N} 1-\mathrm{N} 2-\mathrm{N} 3$

Gambar 3. Kandungan flavonoid bawang dayak pada berbagai umur panen dan dosis NPK 16:16:16

Pada gambar 3 terlihat bahwa perlakuan NPK 16:16:16 memberikan pengaruh terhadap kandungan total flavonoid tanaman bawang dayak, dengan kandungan total flavonoid tertinggi didapat pada perlakuan N1 (pemberian NPK 16:16:16 1,25 g/tanaman) dengan kandungan total flavonoid 30,06 mg kuarsetin/g berat kering pada umur 5 bulan, angka ini jauh lebih tinggi dari kandungan total flavoid pada perlakuan kontrol (tampa pemberian NPK 16:16:16). Pada Gambar 3 juga terlihat kandungan total flavonoid mengalami penurunan pada umur umur panen 6 dan 7 bulan, hal ini terjadi pada semua perlakuan pupuk NPK 16:16:16. Penurunan kandungan total flavonoid ini diduga karena proses metabolit sekunder tanaman bawang dayak

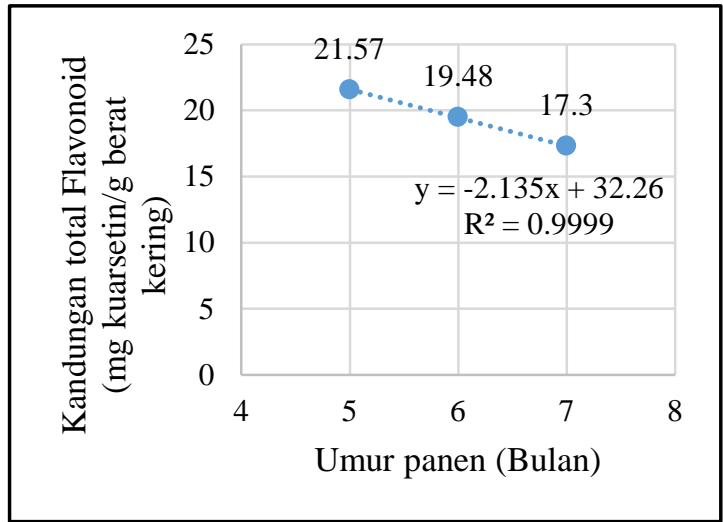

Gambar 6. Kurva hubungan umur panen dengan kandungan total Flavonoid seperti pembentukan flavonoid sudah mulai berkurang, karena tanaman mulai memasuki fase generatif, dan kandungan flavonoid yang terdapat pada umbi tanaman bawang dayak mulai ditranlokasikan ke seluruh bagian tanaman untuk digunakan guna mendukung vase generatif tanaman. Hal ini sejalan dengan pendapat Dixon dan Paiva dalam Melati dkk (2017) yang menjelaskan bahwa akumulasi flavonoid dan fenolik saat fase generatif berkaitan dengan pertahanan tanaman terhadap patogen dan untuk menarik polinator (serangga penyerbuk).

Kurva hubungan umur panen dan NPK dengan kandungan total flavonoid pada tanaman bawang dayak dapat dilihat pada Gambar 4 dan 5.

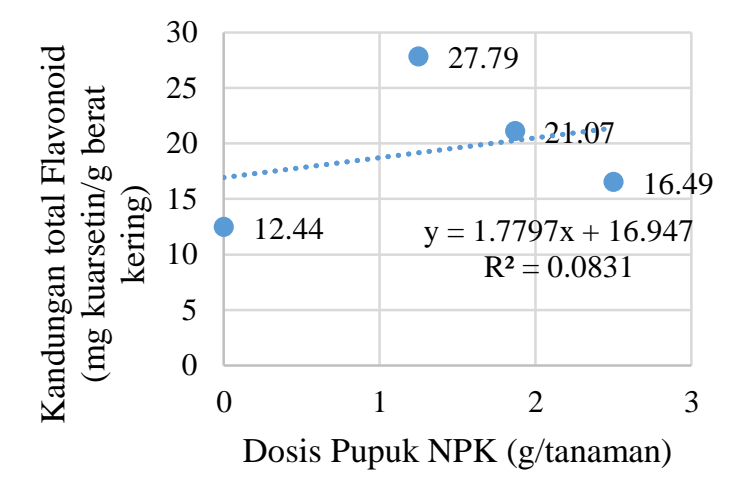

Gambar 7. Kurva hubungan pupuk NPK dengan kandungan total Flavonoid 
Dari data pada gambar 6 terlihat pada hubungan umur panen dengan kandungan total flavonoid, didapatkan nilai $\mathrm{b}=-2,135$, sehingga dapat dikatakan untuk setiap x (umur panen) bertambah 1 bulan, maka y kandunagn total falvonoid) berkurang / menurun sebesar 2,135 . Kurva regresi juga menunjukkan bahwa terdapat hubungan yang erat antara umur panen dengan kandungan total flavonoid. Hal ini diperlihatkan dengan nilai $r$ (koefisien korelasi), dan R2 (koefisien determinasi) diatas 0,90 . Nilai $r$ menyatakan bahwa terdapat korelasi antara umur panen dengan kandungan total flavonoid. Dari nilai R2 (R square) dapat diketahui bahwa terdapat keeratan hubungan yang signifikan antara umur panen dengan kandungan total flavonoid yang diamati dengan derajat keeratan sebesar 0,9999. Hal ini menunjukkan bahwa lebih dari 99\% kandungan total flavonoid dipengaruhi oleh umur panen, sedangkan kurang dari $1 \%$ dipengaruhi oleh factor lain.

Dari data pada gambar 4 terlihat pada hubungan dosis pupuk NPK 16:16:16 dengan kandungan total flavonoid, didapatkan nilai $\mathrm{b}=$ 1,77 , sehingga dapat dikatakan untuk setiap $\mathrm{x}$ (dosis NPK 16:16:16) bertambah 1 taraf, maka y (kandungan total flavonoid) bertambah/ meningkat sebesar 1,77. Kurva regresi juga menunjukkan bahwa terdapat hubungan antara dosis NPK 16:16:16 dengan kandungan total flavonoid. Hal ini diperlihatkan dengan nilai $r$ (koefisien korelasi), dan R2 (koefisien determinasi) diatas 0,08. Nilai $r$ menyatakan bahwa terdapat korelasi antara dosis NPK 16:16:16 dengan kandungan total flavonoid. Dari nilai R2 (R square) dapat diketahui bahwa terdapat keeratan hubungan yang signifikan antara NPK 16:16:16 dengan kandungan total flavonoid yang diamati dengan derajat keeratan sebesar 0,08. Hal ini menunjukkan bahwa lebih dari $8 \%$ kandungan total flavonoid dipengaruhi oleh dosis NPK 16:16:16, sedangkan kurang dari $92 \%$ dipengaruhi oleh faktor lain.

\section{KESIMPULAN}

Dari hasil penelitian yang telah dilaksanakan dapat diambil kesimpullan bahwa:

1. Interaksi pemberian pupuk NPK 16:16:16 dan umur panen yang berbeda tidak berpengaruh terhadap jumlah umbi perumpun, berat kering tanaman dan berat kering simplisia tanaman bawang dayak.

2. Pengaruh utama pupuk NPK 16:16:16 berpengaruh terhadap jumlah umbi perumpun, berat kering tanaman dan berat kering simplisia tanaman bawang dayak. Perlakuan terbaik yaitu pemberian pupuk NPK 16:16 2.5 g/tanaman (N3).

3. Pengaruh utama pupuk NPK 16:16:16 berpengaruh terhadap kandungan total flavonoid tanaman bawang dayak. Perlakuan terbaik yaitu pemberian pupuk NPK 16:16 1,25 g/tanaman (N1).

4. Pengaruh utama umur panen yang berbeda berpengaruh terhadap jumlah umbi perumpun, berat kering tanaman dan berat kering simplisia tanaman bawang dayak. Perlakuan terbaik yaitu umur panen 6 bulan (U2).

5. Pengaruh utama umur panen yang berbeda berpengaruh terhadap kandungan total flavonoid tanaman bawang dayak. Perlakuan terbaik yaitu umur panen 5 bulan (U1).

\section{DAFTAR PUSTAKA}

Advinda, L. 2018. Dasar dasar fisiologi tumbuhan. Budi utama. Yogyakarta.

Amarowicz, R. (2007). Tannins: The new natural antioxidants? European Journal of Lipid Science and Technology, 109, 549551. doi: 10.1002/ejlt.200700145.

Melati. M., Fardyansjah. H., Sandra. A. A. 2017. Perbedaan Waktu Panen Daun terhadap Produksi dan Kadar Flavonoid Tempuyung (Sonchus arvensis L.). J. Hort. Indonesia 8 (2): 136-145.

Dixon, R.A., N.L. Paiva. 1995. Stress-induced phenylpropanoid metabolism. Dalam Melati. M., Fardyansjah. H., Sandra. A. A. 2017. Perbedaan Waktu Panen Daun terhadap Produksi dan Kadar Flavonoid Tempuyung (Sonchus arvensis L.). J. Hort. Indonesia 8 (2): 136-145

Febrinda, A.E., Made,A., Tutik,W., dan Nancy, D.Y., 2013. "Kapasitas Antioksidan dan Inhibitor Alfa Glukosidase Ekstrak Umbi Bawang Dayak". J.Teknol. Dan Industri Pangan. Vol.24 (2).: 161 
Ghasemzadeh, A., \& Ghasemzadeh N. (2011). Flavonoids and phenolic acids: Role and biochemical activity in plants and human. Journal of Medicinal Plants Research, 5(31), 6697-6703. doi: 10.5897/JMPR 11.363

Kuntorini, E.M., Maria, D.A., dan L.Hartanto, N., 2010."Struktur Anatomi dan Aktivitas Antioksidan Bulbus Bawang Dayak (Eleutherine americana Merr.) dari Daerah Kalimantan Selatan”. Berk. Penel. Hayati. Vol.16. Hal: 1

Lakitan, B. 2008. Dasar-Dasar Fisiologi Tumbuhan. Raja Grafindo Persada. Jakarta.

Pratiwi, D., Sri,W., dan Isnindar., 2013. "Uji Aktivitas Antioksidan Daun Bawang Mekah (Eleutherine Americana Merr.) Dengan Metode DPPH (2,2-Difenil1pikrilhidrazil)". Traditional Medicine Journal . Vol. 18(1). Hal: 9; 14

Ramadhan BC, Sandra AA dan Munif G. 2015. Potensi Kadar Bioaktif yang Terdapat pada Daun Kepel (Stelechocarpus burahol (Bl.) Hook. F. \& Th). Bul. Rempah Obat 26(2): 99-108.

Saragih, D., Herawati Hamim dan Niar Nurmauli. 2013. Pengaruh waktu dan dosis terhadap pemberian pupuk urea dalam meningkatkan pertumbuhan dan hasil tanaman jagung manis (zea mays. L). Jurnal Agrotek Tropika Jurusan Agroteknologi Fakultas Pertanian Universitas Lampung. Lampung. 1 (1) : 50-54.

Saxena, M., Saxena, J., \& Pradhan, A. .2012. Flavonoids and phenolic acids as antioxidants in plants and human health. International Journal of Pharmaceutical Sciences Review and Research, 16 (2) : 130-134.

Sulastri, E., Cristadeolia, O., dan Yusriadi., 2015. "Formulasi Mikroemulsi Ekstrak Bawang Hutan dan Uji Aktivitas Antioksidan". Jurnal Pharmascience. Vol.2 (2). Hal: 2; 9. 